\title{
Mental Health Nursing: waiting room intervention in integral health care
}

\author{
Enfermagem em Saúde Mental: intervenção em sala de espera na assistência integral à saúde \\ Enfermería en Salud Mental: intervención en sala de espera en la asistencia integral a la salud
}

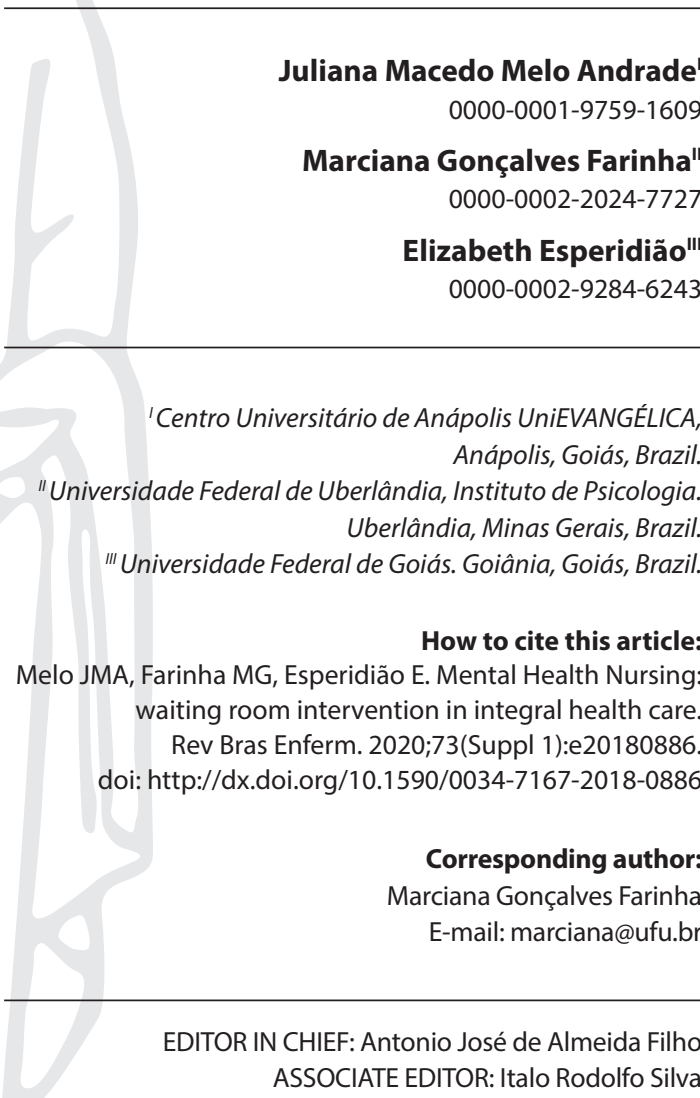

Submission: 03-17-2019
Approval: 04-01-2020

\section{ABSTRACT}

Objective: To describe and to analyze the proposal for intervention in the waiting room as a possibility for Nursing in mental health in group context. Method: Descriptive study with a qualitative approach, convergent care type, developed in a Psychosocial Care Center for Alcohol and Drugs in the interior of the state of Goiás. Results: The service in the waiting room provided moments of reflection, knowledge, learning, listening and exchanging experiences. Final considerations: The meetings in the waiting room favored the articulation between theoretical knowledge and the practice of nursing care in groups, constituting a space with a valuable locus for the development of educational and support actions in health services, to be undertaken by the nurse and, also, by other professionals of the health team.

Descriptors: Psychiatric Nursing; Mental Health; Mental Health Services; Comprehensive Health Care; Nursing.

\section{RESUMO}

Objetivo: Descrever e analisar a proposta de intervenção em sala de espera como uma possibilidade para a Enfermagem em saúde mental em contextos grupais. Método: Estudo descritivo, com abordagem qualitativa, do tipo convergente assistencial, desenvolvido em um Centro de Atenção Psicossocial Álcool e Drogas do interior do estado de Goiás. Resultados: $\mathrm{O}$ atendimento em sala de espera proporcionou momentos de reflexão, conhecimento, aprendizado, escuta e trocas de experiências. Considerações finais: Os encontros em sala de espera favoreceram a articulação entre o saber teórico e a prática do cuidar em enfermagem em grupos, constituindo-se em um espaço com valioso lócus para o desenvolvimento de ações educativas e de suporte nos serviços de saúde, a ser empreendido pelo enfermeiro e, também, por outros profissionais da equipe de saúde.

Descritores: Enfermagem Psiquiátrica; Saúde Mental; Serviços de Saúde Mental; Assistência Integral à Saúde; Enfermagem.

\section{RESUMEN}

Objetivo: Describir y analizar la propuesta de intervención en sala de espera como una posibilidad para la Enfermería en salud mental en contextos grupales. Método: Estudio descriptivo, con abordaje cualitativo, del tipo convergente asistencial, desarrollado en un Centro de Atención Psicosocial Alcohol y Drogas del interior del estado de Goiás. Resultados: La atención en sala de espera proporcionó momentos de reflexión, conocimiento, aprendizaje, escucha y intercambios de experiencias. Consideraciones finales: Los encuentros en sala de espera favorecieron la articulación entre el saber teórico y la práctica del cuidar en enfermería en grupos, constituyéndose en un espacio con valioso locus para el desarrollo de acciones educativas y de suporte en los servicios de salud, a ser emprendido por el enfermero y, también, por otros profesionales de la equipe de salud.

Descriptores: Enfermería Psiquiátrica; Salud Mental; Servicios de Salud Mental; Asistencia Integral a la Salud; Enfermería. 


\section{INTRODUCTION}

Mental health care practices in specialized services, in the context of the Psychiatric Reform, have been reconfigured due to the transformations involved in the psychosocial care model, with repercussions and resignification in practices, in the relationships between professionals and users and inevitably, in work processes, in order to meet the real needs of users, from the perspective of re-socialization and social reintegration.

Psychosocial Care Centers (CAPSs), mental health care units, assume a strategic role in the organization of the psychosocial care network, with diversified care programs offered by a multidisciplinary team. Even though they work from the perspective of free demand, professionals can optimize their educational actions, considering that there are times when users remain in the service waiting for care, and this can bring disquiet and discomfort ${ }^{(1-3)}$.

In this perspective, the waiting room is transformed into an important therapeutic scenario if it is used as another locus of care action geared to the demands of users and their families and/or companions. The care practices developed in the waiting room can transform idleness into an educational moment and contribute to the transmission of information about the problem with which they live, better coping and expression of feelings, increased satisfaction and decreased level of anxiety and stress ${ }^{(2-6)}$.

In the psychosocial care model on which nursing actions in mental health are based, intervention in the waiting room is an excellent care strategy in order to also support the subject's subjective and emotional issues ${ }^{(7)}$. Among the guidelines of Unified Health System -Public (SUS), is the assumption of welcoming the user and their suffering, accepting them unconditionally, in addition to providing guidance from the perspective of health education. Educational care practices favor the development of critical judgment and autonomy over one's own life, environment and social environment, where the person is, and may reveal conditions for them to appropriate their existence ${ }^{(8-9)}$. Each day, nurses have been summoned to the need to focus their actions not only on the user, but also on their families, companions and the community, in general ${ }^{(8,10)}$, with emphasis on group contexts.

Promoting health implies using techniques that enable changes and the strengthening of human existence, in the health-disease process, in a humanized way, which provides efficiency and resolvability ${ }^{(2,8)}$. It is important, therefore, to use different strategies for health work that favor the achievement of the objectives that are proposed and that, above all, can contribute to the development of the citizen who benefits from them ${ }^{(10-12)}$. In this context, organizing actions in the waiting room can mean an important space to convey care practices, articulating the actions with the members of the health team ${ }^{(2,7,13)}$. The possibility of referrals to other health activities in the service itself is expanded, dissemination of the professionals who serve there, as well as strengthening the skills development of professionals including the management of collective interventions.

It is common for people who are in a waiting room environment not to know each other and not have a stable relationship. However, when this activity is installed by the action of the multiprofessional team, group work is usually formed, in a unique and specific way for that context ${ }^{(1,3-6)}$. While customers wait for service, they often talk about their afflictions, illnesses and everyday life. Therefore, it becomes an opportune occasion to raise the problems experienced by them and their needs for attention by the service. Care actions geared to your demands can, by listening and exchanging experiences, reduce anxiety and stress ${ }^{(3-5)}$ and constitute itself as an important health intervention, not always valued by professionals.

However, intervention in the waiting room is still very little used by the health team, despite its therapeutic potential on several fronts of care. In an academic nursing experience, in the waiting room of an outpatient clinic specialized in mental health care for adolescents and their parents, in Rio de Janeiro, the contribution of this activity to the formation and strengthening of the bond between user and health professional was evidenced, to promote open dialogue and, in turn, reduce anxiety and stress while waiting. It was found that the participants talk, exchange experiences with each other, observe, get emotional and express the diversities that emerge through this type of care practice ${ }^{(14)}$.

Another experience was carried out by nursing students at a basic health unit, at a time when the Psychiatric Reform was not yet consolidated, with the objective of identifying basic needs of the population that interfere in mental health. The authors were able to learn that this care practice reduced the stress and anxiety of the people who were waiting for care, providing an exchange of knowledge among those involved ${ }^{(15)}$.

The scientific literature denounces that group technology is quite appropriate due to its interactive nature among participants. Even so, the specialized production on this therapeutic resource is little, and the use of group technologies by nurses is reduced, either in health services in general, or in those specialized in mental health, despite the adequacy of this type of care $\mathrm{e}^{(10-11)}$.

This study focuses on interventions in the waiting room and was based on the experience lived in a mental health service aimed at users in distress due to the problematic use of alcohol and other psychoactive substances, where many people are awaiting care daily prevailed.

\section{OBJECTIVE}

To describe and analyze the proposal for intervention in the waiting room as a possibility for mental health nursing in group contexts.

\section{METHOD}

\section{Ethical aspects}

Research approved by the Research Ethics Committee of the Federal University of Goiás having fully complied with Resolution $466 / 2012^{(16)}$.

\section{Study type}

This is a descriptive study with a qualitative approach; convergent care type, which is characterized by the property of articulation with health care practice, seeking to find alternatives to solve or minimize problems, make changes and/or introduce innovations in the context of the practice in which the investigation occurs ${ }^{(17)}$. 


\section{Study scenario}

It was developed in a Psychosocial Care Center for Alcohol and Drugs (CAPS AD) in Anápolis-GO, with the participation of 160 people with problematic use of alcohol and other psychoactive substances, their families and/or companions aged 18 or over. People who were in the service were excluded for quick procedures such as dispensing medication.

\section{Methodological procedure}

The demand for the intervention occurred for several reasons, all taking into account the National Mental Health Policy, such as Ministerial Ordinance 224/92, which predicts different strategies to serve the population of the CAPSs ${ }^{(18)}$. One of the service professionals was interested in proposing other health education strategies in the context of mental health, with a view to optimizing users' downtime while waiting for care. Still, it was possible to partner with a training institution that offered supervision in the face of the use of new care practices, within the scope of group technologies.

The fieldwork started with the careful planning of the group intervention in the waiting room, constituting itself as an open, mixed, rotating and non-mandatory group, aimed at serving service users, whose objective was to contribute to the reception of participants in the institution, offering them information and support regarding mental health care. The entire process of planning and carrying out interventions was coordinated by a nurse and two nursing technicians, components of the health team, who worked at the study site, with experience in working with groups. There was also the clinical supervision of mental health interventions, carried out weekly, in all phases of the research, by a professional with specific training in the areas of psychiatric nursing and psychology and with performance in group care and mental health care. In supervision, the difficulties of interventions were discussed, better organization of the themes brought by employees, issues demanded by professionals, in addition to planning the next interventions.

The waiting room meetings were held twice a week, before the psychiatric consultation, when there was a greater number of users waiting for care. They had a maximum duration of 60 minutes, with the participation of everyone who accepted the invitation. The intervention included three stages: 1 - Reception, presentation of users and the research project and signing the Informed Consent Form (ICF) after being read and explained; 2 - Offering guidance and support according to the demand of the participants; and 3 - Closing and evaluation.

Different methods were used to approach the participants, including conversation circles and dynamic techniques for groups ${ }^{(19)}$. The environment was duly prepared to make it cozy and comfortable, with ambient sound and aiming at the freedom and privacy of the participants, without undue interruptions.

Data was collected from February to May 2013, through participant observation during the group intervention in the waiting room, in which there were at least three service users participating in the activity. For the purposes of registering this research, 20 group meetings in the waiting room were considered.
The details of the group interventions were recorded in a field diary, and in all consultations there were three professionals involved: while two led the group to another, they observed and noted the significant data that could assist in the analysis process, such as verbal and non-verbal expressions, statements of the participants, in addition to observations about the dynamics of each meeting.

\section{Data analysis}

The notes in the field diary of the meetings were subjected to repeated readings to encode the records relating to each of the three stages considered in the planning of the interventions. Then, the data corresponding to the visits was grouped into categories seeking to identify common patterns and particularities for analysis and description of the intervention ${ }^{(20)}$.

The results were analyzed with a qualitative approach, according to scientific assumptions ${ }^{(20)}$, with the aid of the Atlas TI software, of qualitative research, which allowed to encode the field diary records. Therefore, the citation reference corresponds to the meeting in which the data was obtained, using the letter $E$, followed by the number representing the order of occurrence (E1, E2 and so on).

\section{RESULTS}

Throughout the data collection process, 160 people participated in the group meetings, with an average of 8 participants per meeting. The majority were male (64\%), aged between 31 and 60 years ( $85.72 \%)$, with $43 \%$ of them having 7 to 12 months of treatment both in the service where the study was conducted and in the groups of waiting room.

The interventions were structured in three stages described below, in which the themes emerging from the meetings, reports of feelings and sensations of the participants and the respective therapeutic conduct undertaken by the nursing team will be presented.

\section{$1^{\text {st }}$ stage: Reception and presentation of participants}

Service users were received by the group intervention coordinators and directed to the room for the action, welcoming them and inviting them to settle in. With at least three participants, the sessions began with an explanation of the research, its objectives and the use of the group as a source of data. Afterwards, the ICF was read and signed, which guaranteed the right of participation to the waiting room group even to those who did not want to be part of the research.

Considering that the waiting room group was an open group and, therefore, usually with new members, the coordinators took care to familiarize them with the others, advising on the participation and objectives of the intervention. In addition to reception, all meetings began with the presentation and renewal of the group's contract, including its objectives and operating rules, which could be changed in agreement with the participants.

The contract included aspects related to the secrecy and confidentiality of the expressed content, contained in the ICF, as well as the right to speak, respecting the moment of each one. Everyone 
was free to address matters of interest to them in relation to the situation experienced, demonstrate their feelings and express their emotions, in a space of exchange and sharing of experiences.

For the presentation of the participants, techniques of brief presentation and/or warm-up of the group meeting were used, in order to favor the interaction between them. The facilitator responsible for the group meeting explained the activity and resources, made available according to the technique chosen in planning the intervention: different objects and figures, words that expressed positive and negative feelings, scrap, blank cards, pens and marker pens of various colors, cut-out magazines, drawing paper and others.

Then, using the available materials, each participant introduced themself by saying their name, feelings and expectations of the service and how they were getting to the group. After everyone spoke, the coordinators rescued what had been addressed by those present, emphasizing the shared experiences and feelings and what was common in their initial statements.

\section{$2^{\text {nd }}$ step: Information and support}

In this stage, the conversation circle started with subjects almost always evoked by the participants. Also for that moment, dynamic techniques were used ${ }^{(19)}$ and resources to encourage discussions. Thus, it was possible to use reports or clips on more recurring themes brought by users, construction of panels, from clippings of magazines or newspapers, making of objects with scrap to express their feelings and sensations, as well as making musical instruments for such expression through sounds, music, dance or dramatization.

The most frequent themes revolved around the need for information on the treatment of chemical dependency, aspects related to feelings; difficulties and doubts related to individual and personal experiences; expectations and importance of treatment. According to the needs expressed by the participants, the group coordinators waived their therapeutic conduct (Chart 1).

Chart 1 - Themes and reports addressed by participants in the information and support phase of the intervention in the waiting room and respective therapeutic procedures - CAPS AD of Anápolis, Goiás, Brazil, 2013

\begin{tabular}{|c|c|}
\hline Themes & Therapeutic approaches \\
\hline $\begin{array}{l}\text { 1. Importance and expectations of treatment } \\
\ldots \text { I only started to value life after I started doing the treatment at CAPS. (E4) }\end{array}$ & $\begin{array}{l}\text { Reinforcement of the content expressed by the participants } \\
\text { and guidance on the benefits of treatment to recover the } \\
\text { biopsychosocial balance and the subjects' autonomy }{ }^{(8,13)} \text {. }\end{array}$ \\
\hline $\begin{array}{l}\text { 2. Proper use of medicines } \\
\text { I wasn't taking the medication right and I had three seizures. (E14) }\end{array}$ & $\begin{array}{l}\text { Clarification of doubts about indication, effects and } \\
\text { contraindications of medications and regarding the importance of } \\
\text { following the medical prescription }{ }^{(7,20)} \text {. }\end{array}$ \\
\hline $\begin{array}{l}\text { 3. Advantages and disadvantages of hospitalization } \\
\text { My mother compulsorily admitted me to the sanatorium and today I thank her } \\
\text { because, otherwise, I was already dead. (E1) }\end{array}$ & $\begin{array}{l}\text { Guidance on forms of treatment, modalities and criteria for } \\
\text { psychiatric hospitalization } \\
(7,20)\end{array}$ \\
\hline $\begin{array}{l}\text { 4. Feelings of fear and concern in the face of relapse } \\
\ldots . \text { I'm too scared to relapse and not be able to stop anymore, lose my job... (E18) }\end{array}$ & $\begin{array}{l}\text { Elucidation about possible relapses as expected and part of the } \\
\text { treatment process for chemical dependency. Reflection on aspects } \\
\text { related to relapse, ways of preventing it and coping } \\
\text { (7,20). }\end{array}$ \\
\hline $\begin{array}{l}\text { 5. Anxiety as a hindering factor for abstinent living } \\
\text { Sometimes that anxiety hits, and the desire is to call the dealer ... (E20) }\end{array}$ & $\begin{array}{l}\text { Encouragement of the participants' manifestations regarding the } \\
\text { feeling experienced. Demonstration of breathing and relaxation } \\
\text { techniques to reduce anxiety }{ }^{(20-2)} \text {. }\end{array}$ \\
\hline $\begin{array}{l}\text { 6. The fear of not being successful in treatment and of not maintaining a } \\
\text { stable bond with the spouse and family } \\
\text { Oh! I fear when they have those bad thoughts in my head that I may not be able } \\
\text { to cope and that I will lose their trust (family) again ... (E12) }\end{array}$ & $\begin{array}{l}\text { Listening attentively to the reports and encouraging the expression } \\
\text { of the feelings experienced. Reinforcement of the individual } \\
\text { objective of each participant to deal with their expectations }{ }^{(22-24)} \text {. }\end{array}$ \\
\hline $\begin{array}{l}\text { 7. Difficulties to face the problems resulting from chemical dependence } \\
\text { When you get home drunk or wake up after a drunk and have to face the face of } \\
\text { your son, your wife... Wow! It's too bad... it's such a big fault ... (E9) }\end{array}$ & $\begin{array}{l}\text { Clarification of the biopsychosocial consequences of drug abuse; } \\
\text { Discussion of measures to face the problem; Development of skills } \\
\text { and attitudes towards overcoming difficulties } \\
\text { (7-8,20). }\end{array}$ \\
\hline $\begin{array}{l}\text { 8. Protective factors for drug misuse } \\
\text { Today when I think about my daughters, I think twice before I think about using } \\
\text { the drug, understand? My fight is for them. (E2) }\end{array}$ & $\begin{array}{l}\text { Identification of protective and risk factors in drug abuse. } \\
\text { Encouraging protective attitudes }{ }^{(7-8,20)} \text {. }\end{array}$ \\
\hline $\begin{array}{l}\text { 9. Importance and the role of the family as a partner in the treatment for } \\
\text { chemical dependence } \\
\text { My wife and daughter don't miss an appointment here in the waiting room and } \\
\text { in the family group, they come every week and it motivates me to come too ... } \\
\text { (E13) }\end{array}$ & $\begin{array}{l}\text { Strengthening the role and importance of the family in the } \\
\text { treatment for chemical dependence }(7-8,20) \text {. }\end{array}$ \\
\hline $\begin{array}{l}\text { 10. Faith as an important factor for motivation and coping } \\
\text {.. I like to participate in the group because it increases my hope and my faith } \\
\text { that things will be okay. (E11) }\end{array}$ & Strengthening of faith as a form of coping with treatment ${ }^{(7-8,20)}$. \\
\hline
\end{tabular}




\section{$3^{\text {rd }}$ stage: Closing and evaluation of the meetings}

To end each meeting, group techniques were also used for this purpose, such as reading messages and viewing short videos with motivational and reflective content relevant to the group's experience ${ }^{(19)}$. Participants were invited to reflect on the meeting and, from there, choose a word or message that expressed the meaning of what they experienced in the group.

The service users' assessment of their participation in interventions in the waiting room, regardless of the proposed technique, was always positive, indicating that the service had been useful to help them at that time. All stressed the importance of the space for exchanging experiences and expressed joy at the care and support received from coordinators and group members, as well as from realizing that they were not the only ones facing difficulties in the face of the problems they were experiencing. Most of the reports attest to the satisfaction of participating in the group meetings and their unanimity refers to the fact that the attendance in the waiting room group brought beneficial effects, especially due to the reception by the service and opportunities to express their experiences and by the feeling of self-worth in the social-family context:

The waiting room is different from the other groups I participate in because you talk about everything and hear about all kinds of problems and talk about good things too, about life and how good it is to live well, to feel happy, to value people, the family, the treatment. (E11)

Another aspect emerged by the participants was the nurse's recognition and appreciation in the performance of their duties, especially for the emotional support offered:

... When I found out that it was the nurse who took care of the group along with the other two girls, I thought it was just bullshit. I thought that nursing was just to give an injection [...] [laughs]. (E17)

\section{DISCUSSION}

Group intervention technology is one of the main therapeutic resources in the most different health care contexts. In the field of mental health, it can occupy an important place, as it brings the possibility of contributing to the resocialization of the individual in psychiatric distress, it favors the meeting between users and their families, the latter being, necessarily, the assistants in the treatment and recovery process. However, it is a care practice that requires preparation and planning, which is essential for the good functionality of any group work ${ }^{(9,21,23-26)}$.

For the use of group technologies in all their possibilities, it is necessary that the professional combines theoretical knowledge and experience, in order to conduct the work in an assertive way. Therefore, specific training should be valued, so that care actions are in fact functional and valuable ${ }^{(23,26)}$. Given the importance of group management as a therapeutic tool, there are group management courses for health professionals; some undergraduate Nursing schools already include in their academic curriculum disciplines that discuss group management and techniques as an instrument of nursing care ${ }^{(27)}$.
Intervention in the waiting room is a possibility for the Nursing Care Practice and, in most cases, it should be undertaken in group contexts, within the scope of health education, and can be optimized in services with different specialties. In the study in question, it was developed in a mental health care service aimed at people who make problematic use of alcohol and other drugs, where it was found that the themes brought up by users are part of the repertoire of the particularities and existential dramas of those who attend it.

Group work brings benefits to people with severe suffering, their families and caregivers. They are spaces for guidance on how to relate to the disease, to learn about common myths and beliefs; and make it possible to share experiences and solutions to common problems, enhancing a network for the exchange of experiences, in addition to improving the capacity and ability of $\operatorname{care}^{(13)}$.

Thus, given the necessary competence to manage groups, the service nurse, together with two other professionals of the team, planned this care action taking into account basic aspects such as avoiding advice, valuing and encouraging the participation of all for the exchange of information, knowledge and experience, instead of providing, themselves, the information requested. When considering these aspects, the circulation of information and knowledge among users, family members and health professionals was facilitated and fruitful spaces for health promotion were created.

The scientific literature explains that intervention in the waiting room must keep the focus on the individual and understand them holistically, enabling strategies that go beyond the therapies already discussed in this study, with a view to contributing to patient safety in the waiting room ${ }^{(28)}$. This even allows to observe possible changes in behavior that contribute to the understanding of the person and planning of future therapeutic actions.

It is necessary to perform attentive and refined listening to rectify possible errors of interpretation and understanding on the topic addressed, as well as inserting new knowledge aimed at health promotion, disease prevention, complications and ways of coping with the problem experienced by the person ${ }^{(9,23,26)}$. It is worth mentioning that the provision of the requested information and guidance, alone, has a therapeutic effect on the participants, both by creating an environment conducive to clarifying doubts and obtaining the necessary guidance, as well as meeting their information needs ${ }^{(21)}$.

The statements of the participants corroborate the importance of support and shared experiences with people experiencing similar situations, signaling that the group contributed to the satisfaction of the needs of each member, provided space to consolidate the role of nurses in the group environment of education and support ${ }^{(22-24)}$, in addition to strengthening mutual support among participants.

Using and systematically evaluating group technology as an instrument for nursing care has not been a frequent action of professionals in their practices. However, one of the ways to better take advantage of the group's care is to assess the satisfaction and effectiveness of this type of care, through knowledge of the opinion of its participants regarding the use of the group to meet their demands ${ }^{(22,25)}$. 
In this study, it was found that the assessment of care in the waiting room was useful, as the participants were able to present their feedback on the functioning and effectiveness of the group, contributing with information relevant to the improvement and maintenance of group care, providing a motivational atmosphere for professionals involved in conducting this type of intervention. The intervention group in the waiting room is a strategy that made it possible to bring aspects of daily stress, such as social and economic or territorial problems, which can influence the individual's health status. In addition, this action proves to be a useful space for health education and the sharing of experiences, thoughts, feelings and perceptions of users, seeking the development of strategies to better deal with common difficulties of psychological suffering ${ }^{(20)}$.

The intervention in the waiting room, in relation to the nurse's performance, was equally well evaluated by the participants. Its importance and attributions related to emotional support and guidance were valued when meeting the needs of users. The statements corroborate the value that the performance of this professional exerts in group technologies.

The negative feelings related to the disease process experienced by CAPS AD users, where this study was developed during the intervention in the waiting room, evidenced the need for listening and attention. In general, these subjects value activities that promote well-being, comfort and relief from negative feelings $s^{(22,25-26)}$.

There are studies that discuss the care practices performed by nurses in psychosocial environments, highlighting the difficulty of this professional in defining his duties and the little use of group care in assisting users of mental health services ${ }^{(23-24,29)}$.

The intervention in the waiting room was considered effective by the significant majority of participants and signaled, for nursing care, an excellent care practice, among many others developed by this professional category, in the perspective of the wholeness and humanization of $\operatorname{care}^{(30)}$. It should be noted that the intervention in the waiting room proved to be a significant action in comprehensive health care with inclusive characteristics, moving towards the rehabilitation and re-socialization of people in existential suffering, objectives that remain present in the guiding principles of Brazilian public policies, especially from the Psychiatric Reform ${ }^{(31)}$.

\section{Limitations of the study}

Performing the intervention in the waiting room only twice a week may have been a limitation of the study, as the other users were not reached with their demands. Likewise, as other service professionals were in different services, it was not possible to mobilize them to participate in group meetings, so that they could also offer their assessment of this care practice in view of the participants' demands.

\section{Contributions to the area of nursing and health}

The reflections presented in this article showed the potential and effectiveness for addressing users' demands in unconventional spaces, such as this intervention in the waiting room, which can be configured as an appropriate space for the exchange of knowledge between them and the health team. Although little used by professionals, it brings the possibility of valuing care practices for nursing and health in general, from the perspective of comprehensive health care.

\section{FINAL CONSIDERATIONS}

Considering the potency of the intervention in the waiting room, in which there are people in distress, family members and companions waiting for care, it is usual to arrive long before the time and face idleness in the waiting time, this type of intervention was planned in order to optimize the time they spent in the service, with exchanges of knowledge and experiences that could contribute to their treatment. Even more relevant is to make it possible to discuss topics demanded by the group itself, generally related to the problematic use of alcohol and other drugs, aspects of daily experience such as family and social issues, highlighting the value of the therapeutic action inherent to the intervention.

The interaction between the participants was relevant and significant, not only because of the sharing of their similar experiences, but also because of the opportunity to interact in a favorable environment to clarify doubts and support in coping with conflicting feelings, their existential demands, enabling the (re)construction mechanisms to deal with the suffering caused by illness. Such guidance fully addresses the actions of rehabilitation and re-socialization of people who, for some time, no longer feel they belong in their social environment; actions, these, strongly recommended by the guidelines of public social and health policies in Brazil.

Such care practice was undeniably valued and recognized by the participants of this research, in which it was also possible to give visibility to the role of nurses in a specialized mental health service, such as CAPS AD, which users recognize as a reference in the treatment for addiction of alcohol and other drugs. It also signaled the possibility of changes for participants, such as returning to the world of work, fulfilling dreams, recovering self-esteem and the ability to deal with their dilemmas.

All meetings in the waiting room provided moments of reflection, knowledge, learning, welcoming, listening and exchanging. They contributed to the approximation, interaction and bonding of the user with the different professionals of the team and with the service, promoting discussions also about the functioning of the unit, comprehensive view, multi-professional evaluation and reworking of some of the individual and collective therapeutic projects in the service.

It was configured, therefore, as a valuable care strategy to be offered by nurses and other professionals in the health team, in which it becomes possible to carry out health education actions through sensitive listening, exchanges between group participants and the team in a welcoming space, free from criticism or judgment. The results of this study allow us to propose that this type of intervention is more used in singular therapeutic projects as an intervention action in health services and more undertaken by professionals. This will allow to expand its practices not only for the mental health care network, but also for several health devices, where users are found who remain for long periods waiting for care.

It is important to highlight that planning was a determining factor for the good functioning of group interventions; and, for 
this, the nurse needs to be creative and organized, mobilize other professionals for care and seek support from service managers. Once incorporated into the institutional routine, intervention in the waiting room may be another care practice implemented by the multidisciplinary team. Therefore, it is necessary to raise awareness of the importance and benefits of this type of service to users and to develop skills of the technical team to conduct therapeutic groups of this nature.

The desire to produce something original drove us to develop this study. The aim of this work is to raise awareness among nurses who do not yet use this care strategy or to contribute to those who have already incorporated group technologies in their daily care, so that they do it systematically, in a planned and structured way, given the relevance of results obtained and the great care potential that has been revealed. It is aimed, therefore, to sensitize these professionals as to the importance and benefits of intervention in the waiting room as a possibility of nursing care regardless of the assistance scenario, as long as there is the intention to create a space for the exchange of experiences and knowledge.

Finally, it is considered that this modality of health care contributes to the integration of the user of the services with the team and in the activities developed, bringing them closer and closer to the assistance dynamics, making them responsible for the treatment offered and allowing it to be protagonist of your therapeutic project and agent of change itself.

\section{REFERENCES}

1. Poletto PMB, Motta MGC. Education in health in the waiting room: care and action soothe child who lives with HIV/aids. Esc Anna Nery. 2015;19(4):641-647. doi: 10.5935/1414-8145.20150086.

2. Alves WN, Ávila MB, Santo DCE, Piccinini AM, Ferreira AM. PET-Saúde: experiência na construção da sala de espera no serviço de urgência e emergência. In: Anais do VII Salão Internacional de Ensino, pesquisa e Extensão; 24-26 nov 2015; Alegrete, BR. Alegrete: Universidade Federal do Pampa [Internet]; 2015 [cited 2016 Mar 15];7(3). Available from: http://seer.unipampa.edu.br/index.php/siepe/article/view/15094/4720.

3. Silva SC, COSTA JÁ, Oliveira IICM. A inserção de grupo de sala de espera como promoção em saúde em uma unidade pré-hospitalar. Serv Soc Saúde. 2018;16(1):25-47, doi: 10.20396/sss.v16i1.8651472

4. Fernandes MAS, Souza VS, Borges IC, Andrade DC, Luedy FA, Martins RR, et al. Atividade educativa na sala de espera com pacientes com insuficiência cardíaca. Rev Bras Cardiol[Internet]. 2013[cited 2016 Mar 15];26(2):106-11. Available from: http://www.rbconline.org.br/wpcontent/uploads/RBC-02-art-2013.030.pdf

5. Wild CF, Silveira A, Rosa EO, Favero NB, Gueterres EC, Leal SDS. Educação em saúde na sala de espera de uma policlínica infantil: relato de experiência. Rev Enferm UFSM. 2014;4(3):660-6. doi: 10.5902/2179769212397

6. Reis FV, Brito JR, Santos JN, Oliveira MG. Educação em saúde na sala de espera: relato de experiência. Rev Méd Minas Gerais. 2014;24(Supl1):32-6. doi: 10.5935/2238-3182.2014S004

7. Oliveira EM, Santana MMG, Eloia SC, Almeida PC, Felix TA, Ximenes Neto Francisco RG, et al. Therapeutic Project of crack and alcohol users attended in a psychosocial care center. Rev RENE. 2015;16(3):434-41. doi: 10.15253/2175-6783.2015000300017

8. Dutra VFD, Oliveira RMF. Revisão integrativa: as práticas territoriais de cuidado em saúde mental. Aquichan. 2015;15(4):529-40. doi: 10.5294/ aqui.2015.15.4.8

9. Ritter CB, Aires M, Rotolli A, Santos JLG. Grupo como tecnologia assistencial para o trabalho em enfermagem na saúde coletiva. Saude Transf Soc [Internet]. 2014 [cited 2016 Mar 18];5(3):83-90. Available from: http://incubadora.periodicos.ufsc.br/index.php/saudeetransformacao/ article/view/2494/4023

10. Guimarães NA, Borba LO, Maftum MA, Larocca LM, Nimtz MA. Changes in mental health care due to the psychiatric reform: nursing professionals' perceptions. Ciênc Cuid Saúde. 2015;14(1):830-8. doi: 10.4025/cienccuidsaude.v14i1.22187

11. Gonçalves AM, Vilela S, Terra FD, Nogueira DA. Attitudes and pleasure/suffering in mental health work. Rev Bras Enferm. 2016;69(2):266-274. doi: 10.1590/0034-7167.2016690209i

12. Barros FCP, Costa DA, Fernandes AS, Monte HS, Vilarinho LM, Costa GR. Percepção da família acerca da assistência em um centro de atenção psicossocial infantil. Rev Interdiscip [Internet]. 2016[cited 2016 Mar 16];9(1):79-86. Available from: : http://revistainterdisciplinar.uninovafapi. edu.br/index.php/revinter/article/view/555/pdf_287

13. Sato M, Ayres JRCM. Art and humanization of health practices in a primary care unit. Interface. 2015;19(55):1027-38. doi: 10.1590/1807-57622014.0408

14. Gomes CS, Amaral JS, Dias MO, Silva PFC, Baptista ATP, Almeida IS. Sala de espera para adolescentes e familiares. Rev Aproximando [Internet]. 2015 [cited 2016 Mar 15];1(1):1-5. Available from: http://latic.uerj.br/revista/ojs/index.php/aproximando/article/view/42/57.

15. Esperidião E, Oliveira MAE, Pontiere MSS. Sala de espera: uma ocasião de atenção primária em saúde mental: relato de experiência. Rev Bras Enferm. 1992; 45:145-148.

16. Ministério da Saúde (BR). Conselho Nacional de Saúde. Resolução n. 466, de 12 de dezembro de 2012. Aprova diretrizes e normas regulamentadoras de pesquisas envolvendo seres humanos. Brasília, Diário Oficial da União, 12 dez. 2012.

17. Titonelli ANA. Pesquisa Convergente Assistencial Enfermagem: possibilidades para inovações tecnológicas. Esc. Anna Nery. 2017;21(2):1-2. doi: $10.5935 / 1414-8145.20170041$ 
18. Ministério da Saúde (BR). Secretaria de Atenção à Saúde. Departamento de Ações Programáticas Estratégicas. Guia estratégico para o cuidado de pessoas com necessidades relacionadas ao consumo de álcool e outras drogas: Guia AD / Ministério da Saúde, Secretaria de Atenção à Saúde, Departamento de Ações Programáticas Estratégicas. - Brasília: Ministério da Saúde, 2015. 100 p.

19. Afonso MLM. Oficinas em dinâmica de grupo: um método de intervenção psicossocial. 3. ed. Belo Horizonte: Artesã Editora, 2018.

20. Lüdke M, Andre MEDA. Pesquisa em educação: abordagens qualitativas. 2. ed. São Paulo: EPU; 2013.

21. Munari DB, Furegato AR. Enfermagem e grupos. 2. ed. Goiânia: AB Editora; 2003.

22. Fernandes CNS, Munari DB, Soares SM, Medeiros M. Habilidades e atributos do enfermeiro como coordenador de grupos. Rev RENE [Internet]. 2008 [cited 2016 Mar 18];9(1):146-53. Available from: http://www.redalyc.org/pdf/3240/324027961018.pdf

23. Munari DB, Godoy MTH, Esperidião E. Ensino de enfermagem psiquiátrica/saúde mental na Faculdade de Enfermagem da Universidade Federal de Goiás. Esc Anna Nery. 2006;10(4):684-693. doi: 10.1590/S1414-81452006000400010

24. Silva NS, Esperidião E, Bezerra ALQ, Cavalcante ACG, Souza ACS, Silva KKC. Percepção de enfermeiros sobre aspectos facilitadores e dificultadores de sua prática nos serviços de saúde mental. Rev Bras Enferm. 2013;66(5):745-52. doi: 10.1590/S0034-71672013000500016

25. Yalom ID, Leszcz M. Psicoterapia de grupo: teoria e prática. Trad. Ronaldo Cataldo Costa. 5a. ed. Porto Alegre: Artmed, 2017.

26. Souza AMA, Fraga MNO, Moraes LMP, Garcia MLP, Moura KDR, Almeida PC, Moura EMV. Grupo terapêutico: sistematização da assistência de enfermagem em saúde mental. 2004;13(4):625-32. doi: 10.1590/S0104-07072004000400016

27. Innes K, Elliott, D, Plummer V, Jackson D. Emergency department waiting room nurses in practice: an observational study. J Clin Nurs. 2018;27:e1402-e1411. doi: 10.1111/jocn.14240

28. Flores LB, Quintana AM. Grupo de sala de espera e o câncer de mama: uma tentativa de acolhimento psicológico em ambiente ambulatorial. In: Costa MMM, Leal MCH (org). Políticas públicas e demandas sociais: diálogos contemporâneos II [Internet]. Porto Alegre: Imprensa Livre, 2016 [cited 2017 Dec 29];1(1):363-84. Available from: http://www.eventize.com.br/new/upload/001269/files/2016\%20-\%20 Politicas\%20Publicas\%20e\%20Demandas\%20Sociais\%20II\%20-\%20Sem\%20Nac\%202016(2).pdf

29. Spadini LS, Souza MCBM. Groups carried out by professional nurses in the mental health field. Esc Anna Nery [Internet]. 2006;10(1):132-8. doi: 10.1590/S1414-81452006000100018

30. Ministério da Saúde (BR). Rede de colaboração para a humanização da gestão e da atenção no SUS. Política Nacional de Humanização [Internet]. Brasília (DF): MS; 2014[cited 2016 Mar 18]. Available from: www.redehumanizasus.net

31. Vasconcelos MR, Costa HA, Carvalho NCC, Santo SGE, Miranda TNB, Araújo TS, et al. Álcool e outras drogas na perspectiva da política de redução de danos. Pretextos [Internet]. 2018[cited 2019 Feb 11];3(5):35-50. Available from: http://periodicos.pucminas.br/index.php/ pretextos/article/viewFile/15984/13000 